\title{
BÁRÓ WESSELÉNYI MIKLÓS VÁROSI KÖNYVTÁR
}

Báró Wesselényi Miklós Városi Könyvtár

Cím: Kézdivásárhely, Petőfi Sándor utca 12.

Honlap: https://www.kezdi.ro/baro-wesselenyi-miklos-varosi-konyvtar/

E-mail: kezdivarosikonyvtar@gmail.com

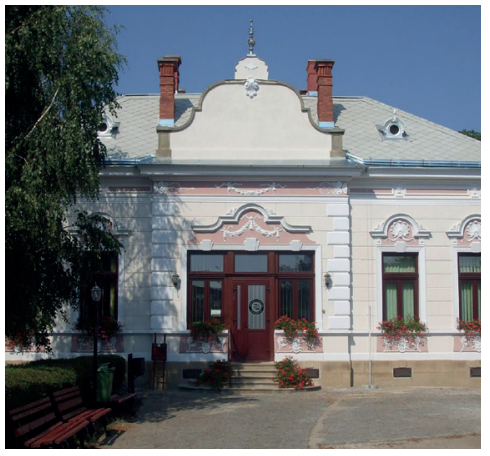

Erdély délkeleti szögletében, a Felső-Háromszékimedence központjában fekszik Kézdivásárhely 20465 fős lakossággal, melynek nemzetiségi hovatartozás szerinti megoszlása: 18612 magyar (90,95\%), 1596 román (7,8\%), 202 cigány $(0,92 \%), 38$ más nemzetiségű $(0,27 \%)$.

Kézdivásárhely első könyvtára, a Kaszinó Könyvtár 1842. december 25-én létesült. Wesselényi Miklós (1796-1850) programjának egyik pontját a társkörök, kaszinók szervezése képezte. Általa jutott el városunk a kaszinó létesítésének gondolatához, igen érdekes körülmények folytán. 1834. július 29-én, hat hétig tartó szárazság után, a tanácsház során tűz ütött ki, amely óriási erővel terjedt tovább. Alig két óra alatt a város háromnegyed része hamuvá lett. A várost ért csapás híre országszerte nagy részvétet keltett, és széles körben megindult a segélyező akció. Báró Wesselényi Miklós 1000 pengő rénes forintot adományozott a városnak. Ez a nagylelkű adomány annyira meghatotta a város polgárságát, hogy a városi képviselő testület nagy lelkesedéssel megválasztotta Kézdivásárhely város díszpolgárának. Ezt azonban a gubernium nem hagyta jóvá, azzal az indoklással, hogy Wesselényinek nincs birtoka Kézdivásárhelyen, és így nem választható a város díszpolgárává. A város nyomban megszerzett egy telket, amely a mai Wesselényi utca és a Molnár Józsiás utca között fekszik, és azt Wesselényi nevére íratta. Így a kormányszék kénytelen volt jóváhagyni a választást. Wesselényi Miklós a telket elfogadta, de azt fel is ajánlotta egy létesítendő kaszinó céljaira. Ez azonban nem vált valóra, mert a kormányszék felbíztatta az eladó egyik távoli rokonát, s az a telket visszaperelte.

Ha elmaradt is Wesselényi tervének megvalósulása, az eszmét többé nem tudták a polgárság lelkéből kitörölni. Papp István református lelkésszel az élen, a város nagyjai megpróbálták ezt az eszmét felszínen tartani és megvalósítását előkészíteni. Papp István azzal az óhajjal állt elö, hogy „,kellene egy olyan hely, ahol az emberek összegyúlnének megbeszélni az egyházi és világi dol-

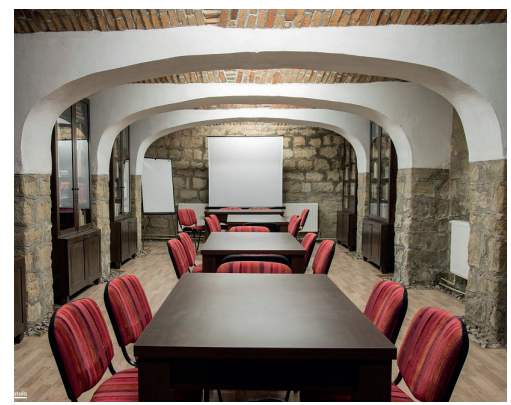




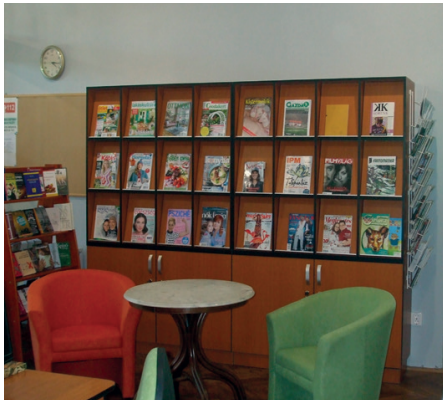

gokat, egymással társalkodnának, könyveket, hírlapokat olvasva magukat és családtagjaikat a műveltség terén fejlesztenék". Így alakult meg 1842. december 25-én a városházán tartott közgyúlésen a Kézdivásárhelyi Társalkodó. Az eltelt idő alatt többször került névváltozásra sor: Polgári Társalkodó, Olvasó-egyesület, Kézdivásárhelyi Kaszinó, Kézdi Rajoni Könyvtár, Városi könyvtár. Az intézmény 1998. június 6-án vette fel a Báró Wesselényi Miklós Városi Könyvtár nevet.

Ahogy változnak az olvasói igények, úgy kell kialakítani szolgáltatásaink sokféleségét, minőségét. Egyre inkább háttérbe kerül a konkrét müre irányuló kérés, és előtérbe jönnek a tematikus olvasói igények kerülnek. Jelenlegi szolgáltatásaink: kölcsönzés, előjegyzés, hosszabbítás, olvasóterem használata, időseknek és betegeknek könyvek házhoz szállítása, irodalomkutatás, tájékoztatás, bibliográfia készítése, internethozzáférés biztosítása, EISZ adatbázisok használata, nyomtatás, fénymásolás, kulturális rendezvények szervezése, játszóházas, meseklubos tevékenységek stb.

2019-ben 2700 beiratkozott olvasója volt a könyvtárnak, a kölcsönzések száma elérte a 26 ezer dokumentumot, a látogatottság pedig az évi 20 ezer főt.

Az állomány 68500 könyvtári dokumentumot tartalmaz, amelynek 60\%-a magyar, 38\%-a román, 2\%-a más nyelvű. 2019-ben 151 saját rendezvényt tartott a könyvtár, amelyből a legtöbbet a meseklub tevékenysége teszi ki. Volt könyvkiállítás, író-olvasó találkozó, időgazdálkodási tréning, ünnepek köré szervezett foglalkozások, tematikus előadások, két napközis nyári tabor, és a 2019 februárjában indított felnőtt olvasóklub.

Mindezt a tevékenységet öt könyvtáros látja el: Bokor Magdolna, Kovács Izabella Andrea, Pánczél Izabella, Szász Laura és Vántsa Judit.

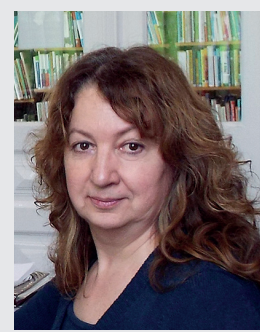

Vántsa Judit

1993-ban az Országos Széchényi Könyvtárban szerzett könyvtári asszisztens, majd 1999-ben a szegedi Juhász Gyula Tanárképző Főiskolán könyvtáros végzettséget szerzett. 2002-ben kiváló minősítéssel elvégezte az informatika-könyvtár szakot a Szegedi Tudományegyetemen. Doktori kutatásait az Eötvös Loránd Tudományegyetemen folytatja, doktori témája az 1945 romániai magyar közkönyvtárügy megjelenése a szaksajtóban. 1990 őszétől dolgozik a Báró Wesselényi Miklós Városi Könyvtárban, 2001 óta az intézmény vezetője. A könyvtárban rendszeresen szervez és tart olvasásmotivációs előadásokat, olvasóklubokat. 